\title{
Costume as a Form of Visualization of Ethnicity: From Tradition to Modernity
}

\author{
Daria Yurievna Ermilova \\ Russian State University of Tourism and Service. Email: id311@yandex.ru
}

\begin{abstract}
The article traces the transformation of visualization of a person's ethnicity through costumes - from traditional to modern. The object of the study is to understand the costume as an informational and sign structure. The topic of the study is the visualization of ethnicity through costumes from a historical perspective. The study aims to identify the specific characteristics of visualization of ethnicity in traditional and modern costumes. The study hypothesis is that, unlike traditional costumes that demonstrated regional and national affiliation, modern "Western" clothing has mostly lost these functions. Although in some regions costumes are still relevant as a "living" tradition, national clothing is disappearing from everyday life. Ethnic style using regional and national traditions as a source of stylization does not present an indicator of a person's nationality. Nevertheless, some examples of modern clothing visualizing ethnicity can be found. The functional and semiotic approaches to the analysis of costumes serve as the basis of the study. Since the late Middle Ages, the development of urban dress in Western Europe has been determined by fashion rather than tradition. In Russia, the process of an urban costume losing the function of visualization of ethnicity began with the reforms of Peter the Great and for peasants' costumes, this process did not start until the middle of the 2oth century. At the beginning of the 21st century, traditional costumes were mostly worn by ethnic minorities as a symbol of national identity and self-affirmation. Referring to others' traditions as a source of fashion innovations led to the emergence of ethnic style. Ethnic style is characterized by a superficial attitude towards the source. Ethnodesign, on the other hand, follows the principle of deep and thoughtful care about the tradition which gains relevance due to the rise of glocalization manifesting in the intensification of regional differences. Although the proponents of ethnodesign insist on the ability of design to integrate traditional ethnic symbols into modern culture, the question is about the ability of modern people to understand the meanings contained in traditional forms remains. The present article identifies the cases of a costume serving the function of visualization of ethnicity in modern society.
\end{abstract}

Keywords: visualization, ethnicity, traditional costume, ethnodesign, modern costume, functions of a costume.

\section{Introduction}

Since the Paleolithic times, a costume has been the most important means of human identification, visual and instant. This function of a costume did not lose its relevance by the beginning of the 21st century - a costume allows one to decide an individual's social group. For example, an anthropologist K. Fox describes various nuances of social differences in modern clothes of British people (Fox 2004, 424). Both traditional and modern costumes present informational and sign structures: "Clothing as a phenomenon of visual culture presents an informative sign structure that has both basic and flexible, constantly changing elements" (Liausheva 2019, 104).

(c) AesthetixMS 2020. This Open Access article is published under a Creative Commons Attribution Non-Commercial 4.0 International License (http://creativecommons.org/licenses/by-nc/4.o/), which permits non-commercial re-use, distribution, and reproduction in any medium, provided the original work is properly cited. For citation use the DOI. For commercial re-use, please contact editor@rupkatha.com. 
According to the principles of the ecology of culture, the relevance of ethno- and eco-design as well as the problems of preservation of regional and national traditions and the uniqueness of material culture call for studying the problem of visualization of ethnicity in modern society, particularly in costumes as ancient and descriptive identity marker.

The goal of the present study is to identify the specific characteristics of identity visualization in traditional and modern costumes. In ancient times, a person's costume allowed them to identify their clan and tribe (for example, in the costumes of the Celtic peoples, the role of a clan identifier was played by the "tartan" pattern of the fabric of plaids and kilts among Scottish people). In traditional societies, ethnicity was primarily identified based on a person's appearance, specifically their costume, both by their fellows and "foreigners". However, foreigners could not "read" all the information about the wearer demonstrated by the costume.

The sign function of a traditional costume (national costume, ethnic costume, traditional folk clothing) was as important as the magical function. Moreover, some scientists interpret traditional costumes as an example of the non-verbal text of the culture of the people (19). The sign function of traditional clothing is studied in the classical works of P.G. Bogatyrev and G.S. Maslova. Among other functions of a traditional costume, P.G. Bogatyrev indicates a regional function and a function of indication of religion (Bogatyrev 1971, 340). A famous Soviet ethnographer N.I. GagenTorn directly calls folk clothing "a person's passport". Each element of a costume, its color, and ornament performed magical, symbolic, and sign functions. In traditional society, a costume was a part of ritual practices. Traditional costumes serve these functions for millennia and preserved them to the present day, especially in the countries where people adhere to the traditional way of life.

The traditional costumes' function of demonstration of national and regional affiliation has been thoroughly studied and continues to interest modern researchers both in the general sense, in the works of O.A. Boeva, N.M. Kalashnikova, and E.E. Levkievskaia and concerning the costumes of a specific region, for instance, in I.G. Petrov, M.M. Sodnompilova, A. Fieschi, H.C. Ross, etc.

The various aspects of visualization of ethnic identity in modern costumes were examined by C. Seeling, S.A. Liausheva and T.S. Pozdniakova, and A.V. Vasilchenko. V.E. Dobrovolskaia conducted a comparative analysis of the sign functions of traditional and modern costumes. The issues of regional design and ethnodesign were researched by K.A. Kondrateva, A.A. Golovnev, O.N. Danilova, M.S. Kukhta, and T.V. Poidina. The problem of glocalization and its influence on modern material culture was established in the works of M. Cleveland and M. Laroche.

\section{Materials and methods}

The study implements the functional and semiotic approaches to analyse costumes as informational and sign structures, as well as art history and stylistic analysis of traditional costumes, European fashionable costumes, and modern clothing in the "Western" societies. The adopted definition of the concept of "clothing" is "a system of non-verbal means of communication contributing to a more active interaction between people as their position in space and time changes" (21, p. 121). The conclusions are made by analysing the development of European tradition in clothing that became a global mark at the beginning of the 21st century. The aspects of visualization of ethnicity in modern costumes were examined by the example of ethnic style in design, as well as regional or ethnodesign. 


\section{Results}

In some regions of the world, traditional costumes present a "living" tradition and the representatives of the ethnos in question wear it in their daily life (often at the same time as European clothing, as in India) preserving its functions - not only the social ones but also the agerelated, magical, ritual, ceremonial, etc. - such regions include South America, India, Pakistan, Southeast Asia, and Africa. Even in technologically advanced Japan, despite the reorientation towards Western fashion that occurred after World War II, kimonos are worn in certain situations (Fieschi 2002, 128). In the USSR, traditional costumes were preserved in Central Asia, the Caucasus, by some indigenous peoples of Siberia and the Far North, and many ethnic groups in rural areas which was determined by the conservative lifestyle of the peasantry. In modern Russia, traditional costumes are worn alongside fashionable ones in the North Caucasus and Dagestan and by the peoples of Siberia and the Far North who follow a traditional way of life - for example, nomadic reindeer herders - the Nenets of Yamal (Golovnev 2017, 6-15).

During a certain point of time, the costumes of Western Europe were also traditional ones from the costumes of the ancient Celts and Germans to the costumes of the early Middle Ages. In the late Middle Ages, the development of urban costumes started to determine a new social phenomenon of fashion which emerged at the end of the 12th century under the influence of the "urban revolution" and the Crusades (Ermilova 2019, 6-7). A fashionable costume presents the opposite of a traditional one as it has gradually lost many of its functions: the age-related, magical, ritualistic, the function of identification of marital status, etc. The demonstration of social status became its main function. The costumes of Western Europe started to differ from the costumes of other regions in its cut that changed under the influence of fashion (the 13th century was marked by the "revolution in the cut" which consisted in the fact that tailors learned to create sweeps of volumetric shapes on a plane using darts and reliefs) which can be considered a "European tradition" in clothing (Ermilova 2019, 120-131). Fashion largely depended on the social class and the authorities tried to restrain the imitation of the noble bourgeoisie via legislative measures.

In the Late Middle Ages and the Renaissance, European costume was gradually losing its function of visualizing ethnicity. In the 14th century, the general European fashion formed for the first time, and the process of elimination of specific national features in the costume of the urban population, especially the nobility, began. The first example of general European fashion is the Spanish fashions. The peasant costume which presented a product of subsistence farming retained its national characteristics until the beginning of the zoth century.

In the 17th century, this trend intensified further. The legendary Sun King, Louis XIV who promoted the French court fashion as a common European standard by all means pursuing political and economic goals achieved tremendous success in this field. France became the main fashion trendsetter not only in Western Europe but also across the world. Due to colonization, fashion became truly global and all specific regional and national characteristics were eliminated (7, pp. 200-202).

The bourgeois revolutions that abolished the class fashion and the industrial revolution allowed to replicate the fashionable designs in order to create the preconditions to democratize fashion and the formation of the mass market. In the era of Napoleon I, the French peasant became the first buyers joining market relations. These trends also determined the development of peasants' costumes in other European countries in the 19th century. Moreover, compared to a fashionable urban costume, the traditional home-made clothing was perceived not only as unfashionable but also as unattractive from a social point of view since it was associated with low social status (in 
Russia, a similar attitude towards bast shoes and poneva was present as they were considered the "rustic" elements of clothing compared to the kokoshnik and the sundress which even became the elements of the court costume under Catherine II and Nicholas I). All these factors lead to the spread of urban fashion and almost complete elimination of traditional costumes in Western Europe by the beginning of the 2oth century. Today, traditional clothing exists in Europe as an object of museum collections, costumes of ethnographic ensembles, and an attribute of ethnic festivals (for example, the famous Oktoberfest beer festival in Munich). However, some attempts to revive national costumes were made in the zoth century due to the globalization of fashion - this trend can be illustrated by the traditional Bavarian dress "tracht" which was popular in Nazi Germany as opposition to European fashion. However, this tendency was "defeated" along with the Third Reich (Vasilchenko 2009, 288).

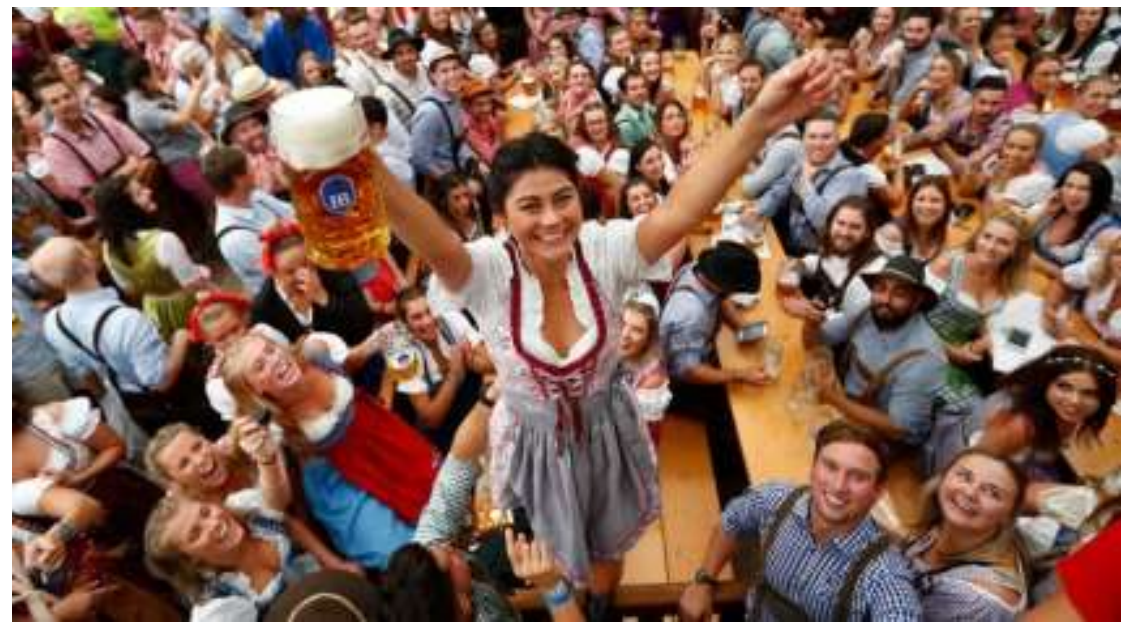

Fig. 1. Bavarian costumes at the Oktoberfest Munich 2018

(URL: https://m.gazeta.ru/social/photo/piva -- po grud kak prohodit oktoberfest.shtml)

In Russia, the process of elimination of the function of visualization of ethnicity started with the reforms of Peter the Great. However, these reforms did not affect peasants' costumes for primarily economic reasons. The process of urban fashion spreading in rural areas accelerated after the abolition of serfdom in 1861. This process became especially rapid after the civil war in the 1920 s and 30 due to collectivization and industrialization. Millions of former peasants and their children became the new urban residents and traditional clothing gave way to urban fashion. In the $1920 \mathrm{~s}$ and 3os, traditional clothing became a marker of the past. This period was marked by the emergence of the opposition between traditional costumes and urban clothing with the traditional costumes representing backwardness and urban clothing indicating a person belonging to the advanced part of society. Moreover, in contrast to the pre-revolutionary times, the function of an urban costume most significant to peasants was not the social function (the revolution abolished social differences in clothing along with the previously existing social classes) but the aesthetic one. A person was considered well and beautifully dressed if they wore urban clothing. Furthermore, it was urban clothing that was perceived as "correct" and "decent" while the familiar folk costumes ceased to be recognized as clothing corresponding to social norms (Dobrovolskaia 2015, 286). 
5 Costume as a Form of Visualization of Ethnicity: From Tradition to Modernity

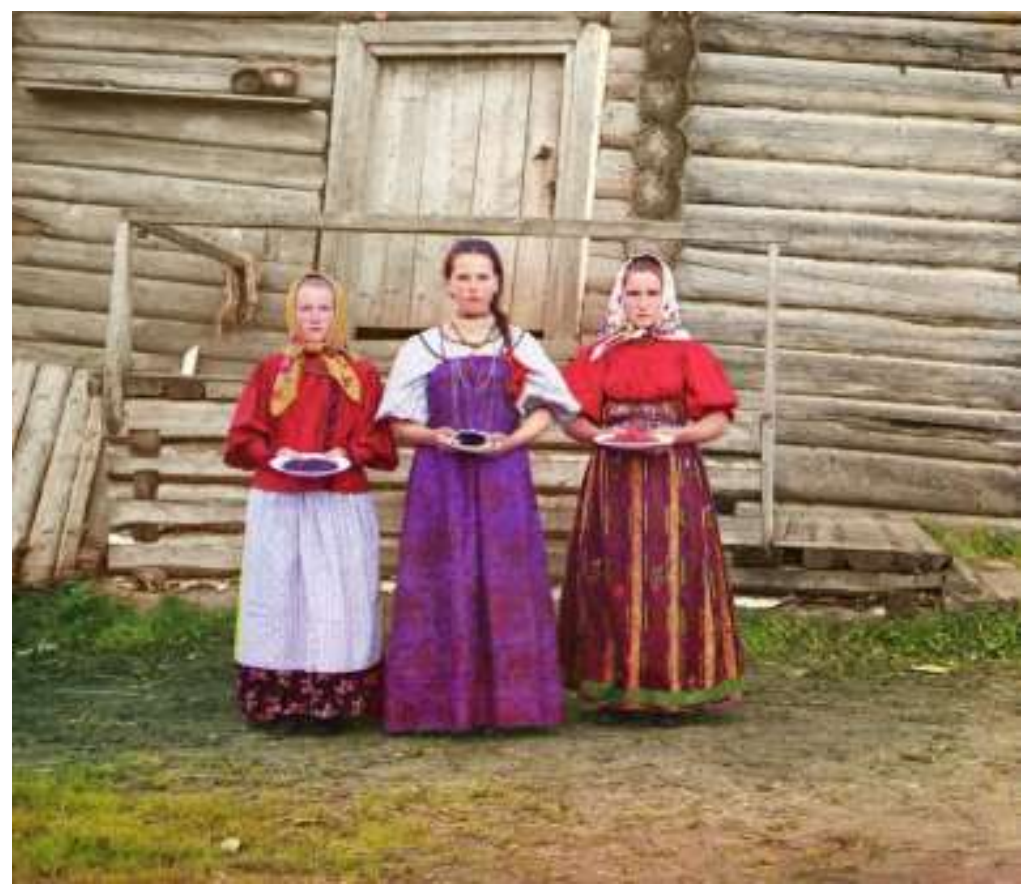

Fig. 2. Country girls, neighborhood of Kirillov on the Sheksna river, 1909 / Sergei Prokudin-Gorskii (URL: https://www.pinterest.es/pin/425660602261245451/)

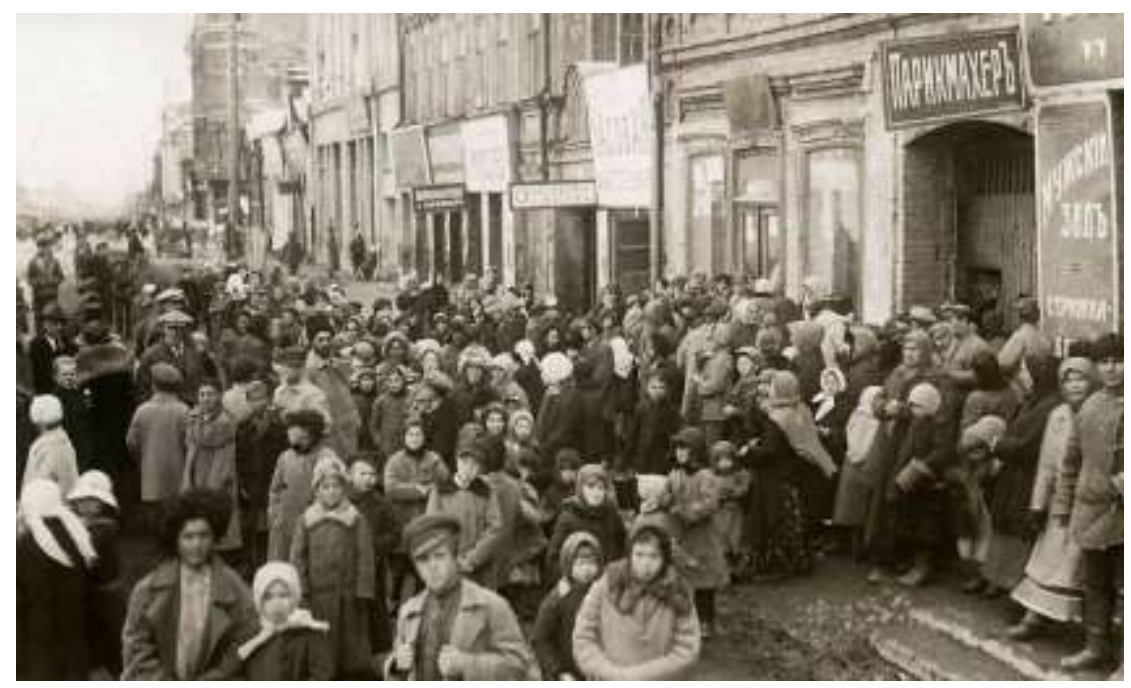

Fig. 3. National costumes on the streets of Petrograd in 1917

(URL: http://jrate.ru/post/94121/305719) 


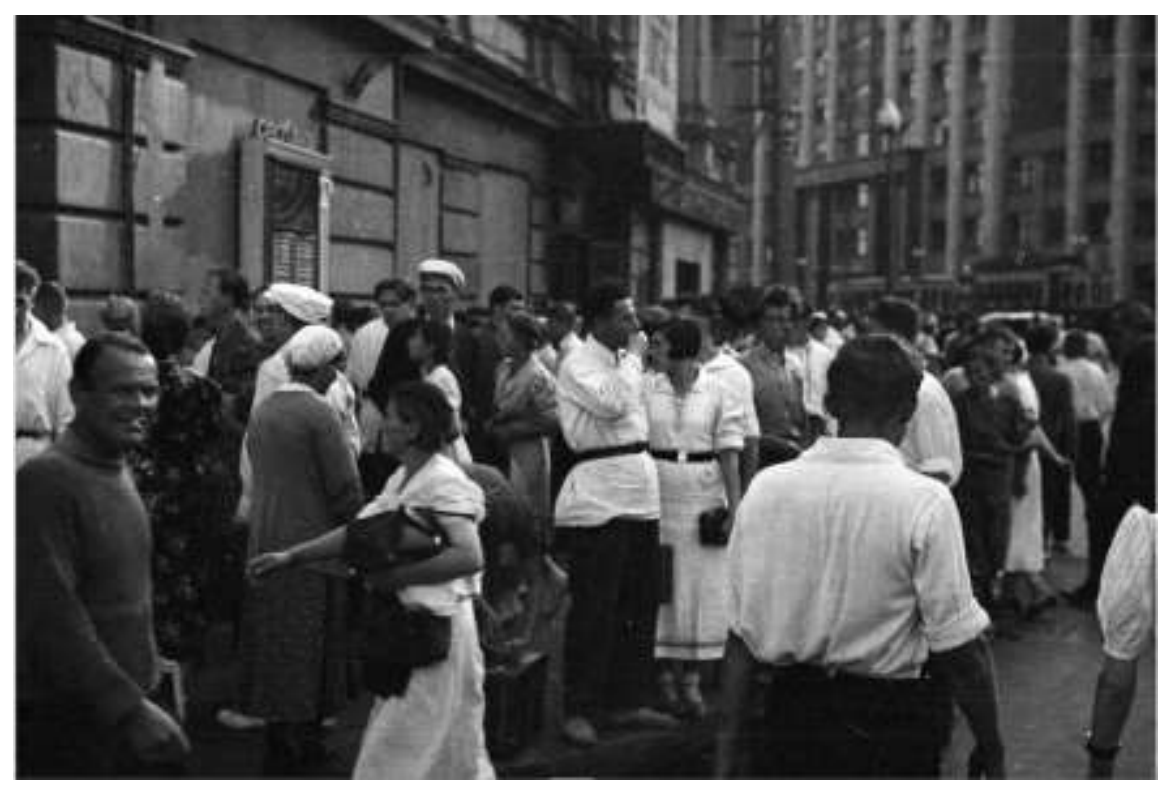

Fig. 4. Moscow in 1939

(URL: https://img-fotki.yandex.ru/get/3306/97833783.bfd/o 1223b2 112dc7oe XXXL.jpg)

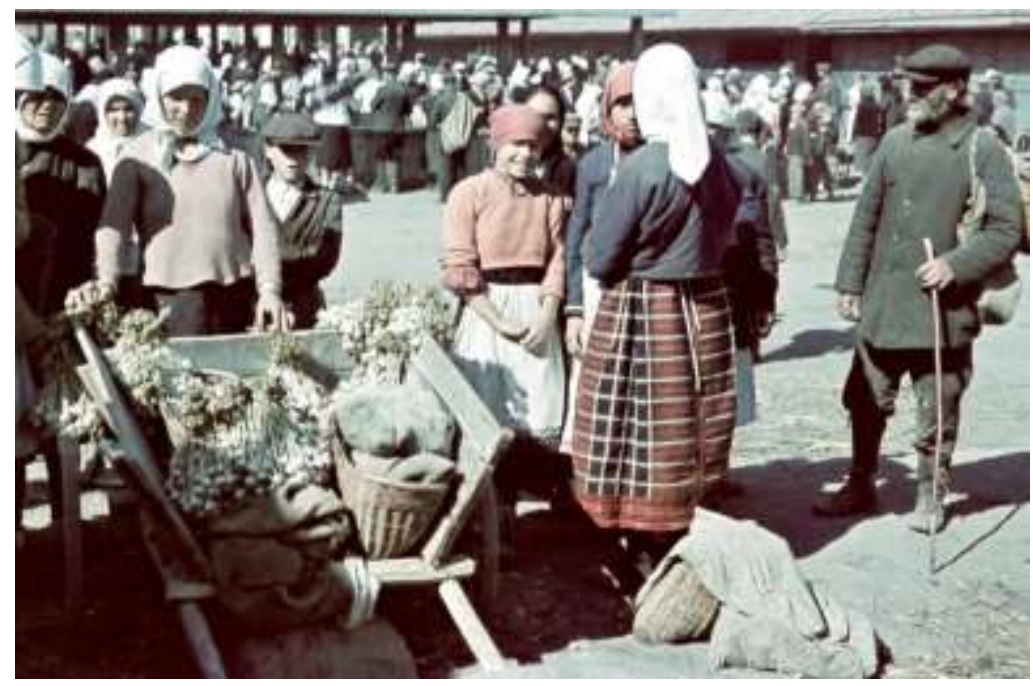

Fig. 5. Civilians at the market in the occupied city of Alekseevka, Voronezh region, $194^{2}$

(URL: https://www.liveinternet.ru/community/lj humus/post439521826/)

The presented pictures of the streets of Russian cities in the early 1920 clearly show people in national costumes, while in the photo taken in the 1930 s they are almost gone. This demonstrates the fact that people from villages and other regions of the country adapted to urban fashion. However, this tendency did not affect villages themselves as photographs taken by the German military during the Great Patriotic War in occupied villages show many examples of traditional clothing like ponevas and bast shoes. After the war, traditional costumes started to rapidly lose the status of daily wear, especially in the European part of Russia. At the beginning of the 19th century, traditional costumes were worn rarely and only for special occasions, predominantly weddings, and not by Russians but by the representatives of the "small peoples" of Russia as a symbol of national identity and self-affirmation as a people. 
In some regions, traditional ideas about costumes as magical items survived to the present day. For example, the Buryats preserved the ideas "according to which the soul can enter one's clothing and become a part of it served as a basis for the prohibition of lending someone one's (already used) clothes, giving it as a gift, or exchanging it for something which was widespread in the past among the Mongolian people everywhere and is now found in Kalmyks and Buryats" (Sodnompilova 2013, 15).

Traditional costumes of migrants from Africa and the Middle East in Western Europe present a topic calling for specialized research. Women's Muslim costumes - hijabs and nikkabs are worn in European capitals and large cities almost more often than in their historical homeland. Stubborn adherence to traditional costumes despite the legal prohibitions in some countries presents not a mere tribute to tradition but a way of self-affirmation.

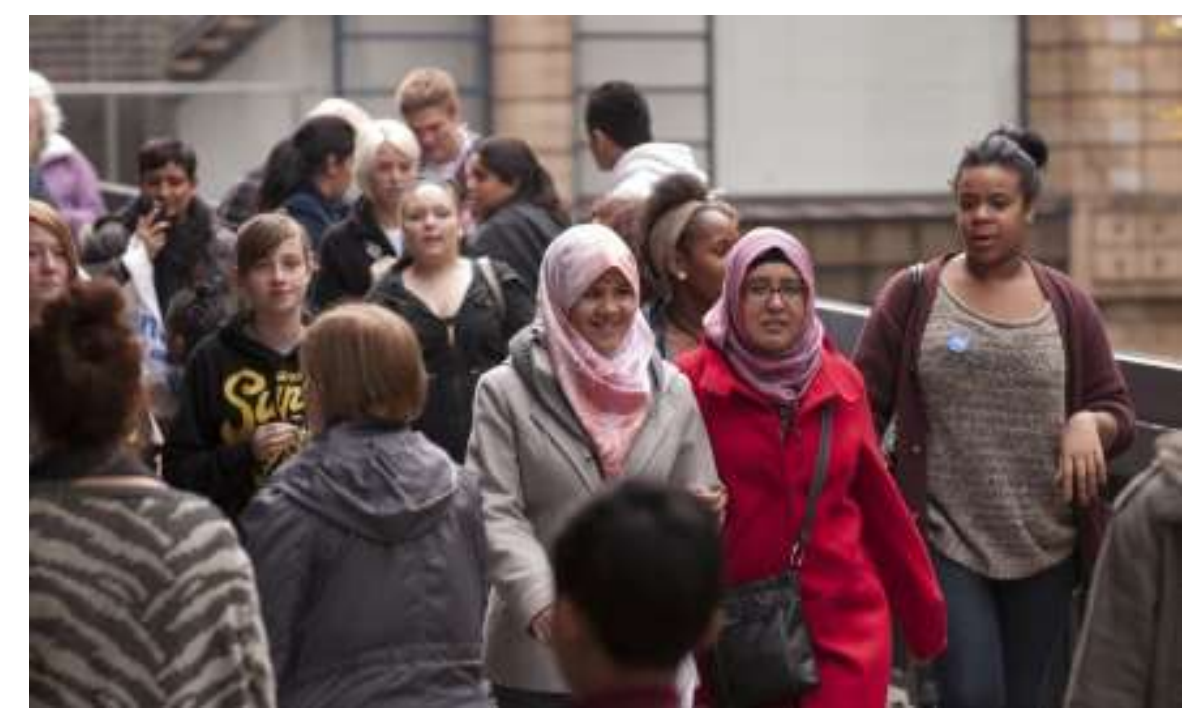

Fig. 6. Hijabs on the streets of London, 2016

(URL: https://uk.makemefeed.com/2016/o4/o2/britains-values-were-founded-in-europe-how-can-weleave-andrew-graham-980815.html)

The gradual disappearance of traditional clothing from everyday life in Europe along with the loss of the function of visualizing ethnicity was accompanied by an appeal to use foreign traditions as a source of innovation in European fashion. Despite religious antagonism, starting from the 12th century, the century of the Second and Third Crusades, the traditional costume of the Middle East (Persian, Arabic, and later Turkish) served as a source of new elements in European fashionable costumes, the examples of borrowed elements including turbans, hanging sleeves, button closures, swing clothes, and the ornamental motifs of Venetian fabrics. Turkish motifs can be seen in the fashion of the 17th-18th centuries, the era of romanticism, and the 1910s. Chinese motifs became a certain sensation in the interior fashion of the 17th-18th centuries (white and blue porcelain, lacquer screens, painted wallpaper, chinoiserie-style furniture) while weavers and embroiderers imitated Chinese themes. The enthusiasm for Chinese exoticism reemerged in the Art Deco era while Japanese motifs first gave rise to the "Japanese mania" of the 1870 -80s and were then stylized and transformed in the Art Nouveau style. In the Art Nouveau era, kimonos worn as home clothes were no less popular than Japanese prints, fabrics, and porcelain; in the Art Deco era, lacquer screens were just as iconic of a fashionable item as jewelry in the style of Tutankhamun or Russian kokoshniks worn as evening headdress. 


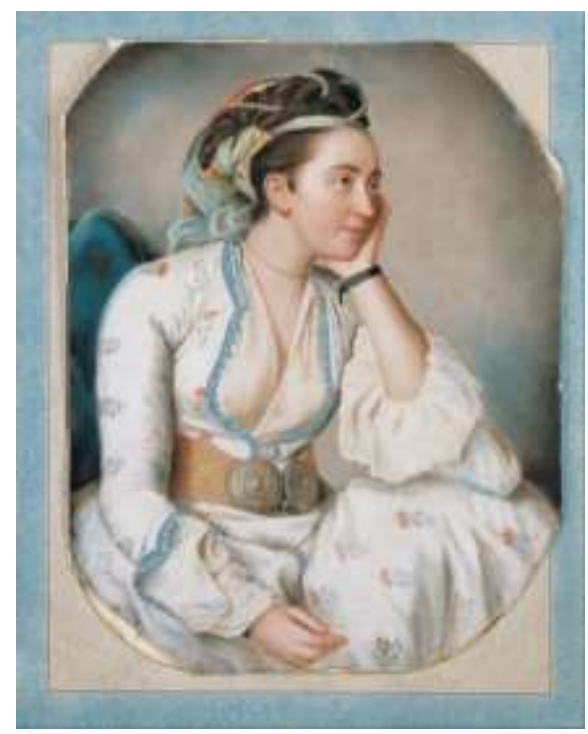

Fig. 7. Jean-Étienne Liotard, A Woman in Turkish Dress, 18th century

(URL: http://iskusstvoed.ru/2017/10/o7/vostok-i-rokoko-shinuazri-tjurkeri-zhapo/)

Eventually, the ethnic style conquered mass fashion in the second half of the 196os due to the hippie subculture. On the one hand, authentic ethnic costumes worn by hippies (Mexican ponchos, Indian saris, Afghan sheepskin coats, Arab djellaba) provided them an opportunity to create a unique style in clothing which they considered the most important way of self-expression as opposed to the official fashion imposing standard images. On the other hand, ethnic borrowings responded to the hopes of rebellious young people who had lost faith in the European and American way of life and sought an alternative to the Western civilization in Eastern philosophical practices and lifestyle (Seeling 2000).

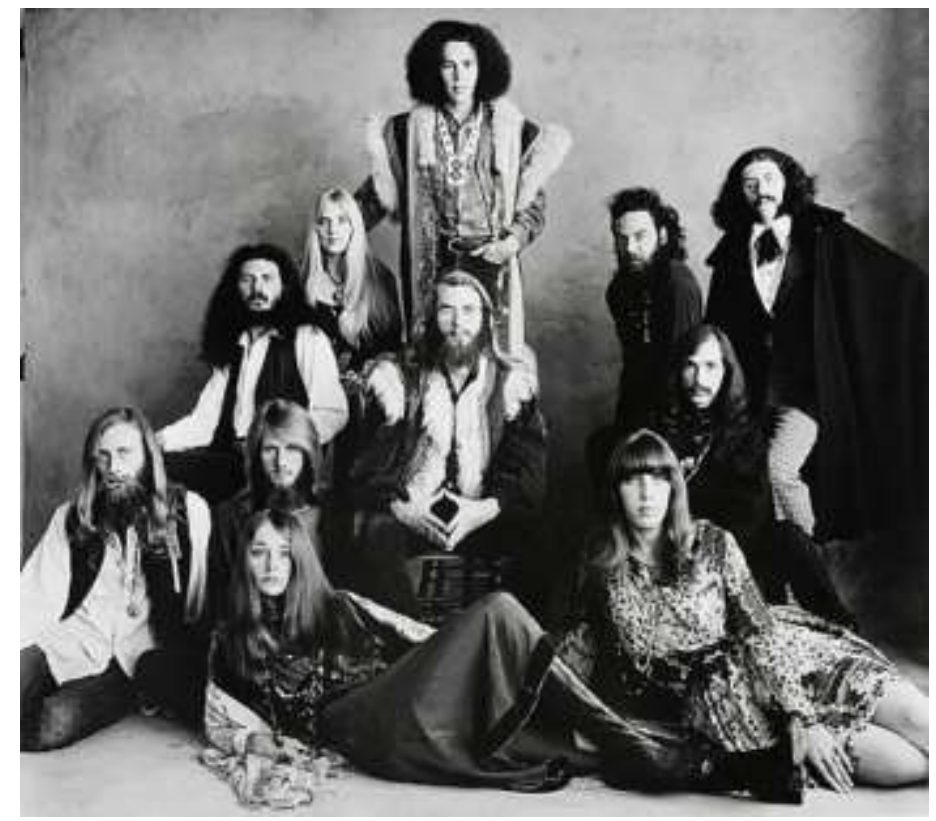

Fig. 8. Hippies in San Francisco in 1967. Photo by I. Penn

(URL: https://govza.ru/2017/o8/26/znamenityi-fotograf-irvin-penn-i-ego-kultovye-snimki/) 
Following this trend, exotic cuisine (Indian, Mexican, Chinese, and Japanese) came into vogue at the end of the 1960s - the beginning of the 1970s. Meanwhile, adherence to national cuisine and food traditions presents a marker of regional or ethnicity as important as clothing (which was ironically demonstrated by A. Christie through the images of Hercule Poirot, a gourmet preferring exquisite French cuisine, and Inspector Japp, an admirer of simple English food). It should be noted that in the USSR, Caucasus and Central Asian people who were strictly regional became rather global - all Soviet people gladly ate and cooked kebabs, lobio, dolma, lavash, pilaf, and Ossetian pies regardless of nationality.

In the 1970s, the ethnic style became one of the most popular styles in fashion and did not lose its popularity neither in the 1980s, nor in the 1990 or or 2000 and only the sources of its inspiration changed from the Arab East to North Africa, Southeast Asia, or the Balkans. The interest in a certain region in terms of its ethnic motifs emerging in fashion is typically inspired either by military conflicts (the Arab-Israeli war in 1973, the wars in the Balkans in the 1990s) or by the development of mass tourism in the area. Couturiers, fashion designers, and brands also emerged that achieved great success with their ethnic style collections. Yves Saint Laurent was a true icon of ethnic style in the late 1960 s and 7os with his African, Hispanic, and Chinese collections, the most famous collection of the series being "Russian ballets/operas". The Kenzo, Gianfranco Ferre, Romeo Gigli, and Etro fashion houses also worked in the ethnic style. In the 1990s and the 2000s, ethnic models appeared in the collections presented by Jean-Paul Gaultier, Dries van Noten, Antonio Marras, and John Galliano who was the first to combine ethnic style with historicism.

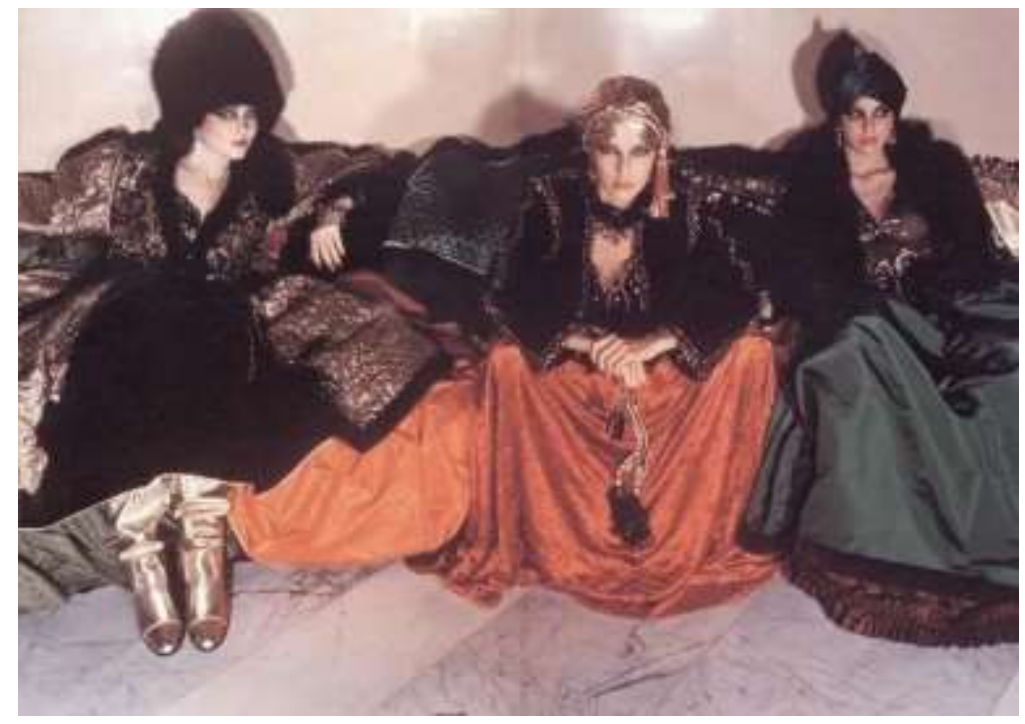

Fig. 9. Models from Yves Saint Laurent's collection "Russian ballets/operas", 1976 (URL:

http://yulialahmanik.blogspot.com/2014/o7/lection-my-yves-saint-lauren-with-katya.html?m=1)

Unlike fashionable clothing collections in which ethnic motifs alternately go in and out of fashion, the interior design presents the area in which ethnic style is invariably popular. At one moment, interiors in the style of Japanese minimalism are in style, then the focus shifts to the style of maharajas, then to the African style, then the style of Morocco is in vogue. However, the popularity of ethnic style does not mean that modern costumes and material culture (primarily the house interior) demonstrate ethnic identity. As was written in fashion magazines back in the 1970s, a modern woman can choose who she wants to become - a gypsy, a Chinese, an Eskimo, or an Indian: "By choosing her clothing, a woman chooses the image she likes. Clothing should be eclectic enough to convey the versatility of the personality not limited to one style" ${ }^{\text {. }}$. Therefore, ethnic motifs 
only present one of the opportunities to highlight one's individuality rather than a means of demonstrating one's ethnicity.

Unlike ethnic style demonstrating an external, superficial attitude towards the material artifacts of national cultures, ethnodesign or regional design follows the principle of deep and thoughtful care about the tradition and the preservation and maintenance of values of traditional cultures based on studying the patterns of its formation: "Ethnodesign is the study and actualization of ethnically distinctive technologies" (Golovnev 2007, 6). The relevance of ethnodesign is associated with the rise of glocalization - a process opposite to globalization but developing in parallel with it manifests the increase of regional differences in the economy, social structure, and culture. Instead of the economic and cultural unification, there is separatism and increased interest in local differences and ancient regional traditions. The emergence of ethnodesign amplified the relevance of the problem of ethnocultural identity in design - the ability of a designer to embody the traditions of the spiritual and material culture of an ethnos in their projects adapted to modern technologies and lifestyle (Kondrateva 2000). Identity implies a person's awareness and experience

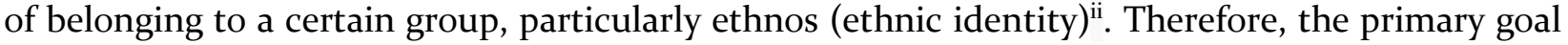
of ethnodesign is the "reconstruction of traditional functions, every day and artistic values, styles and ways of life inherent to the regional ethnocultural tradition" (Poidina 2018, 136). Ethnodesign is also closely related to ecodesign since it focuses on using environmentally friendly technologies.

Same as the ethnic style, ethnodesign can implement various methods of interpretation of the source - citation, stylization, interpretation of shapes, materials, and ornaments. However, it aims to preserve the initial meaning of these motifs, particularly the symbolism of traditional ornaments, as much as possible. Nevertheless, the problem lies in the fact that a modern person does not perceive the ancient language of symbols and is unable to "read" it. Traditional ornamental motifs (circles, crosses, swastikas, rhombuses, triangles, zigzags, spirals, waves) that used to possess cosmogonic meaning convey the essence of the universe are no longer perceived that way. In European art, ancient symbols were replaced by pictorial motives of primarily artistic value quite a long time ago - in the art of Ancient Rome. It could be stated that only two ornamental motifs of the 2oth century acquired a new meaning compared to that of ancient ornaments in terms of the strength of impact and perception by people - a five-pointed star and swastika. At the turn of the 2oth and the 21st centuries, a modern person acquired new signs generated by new communication technologies - emoticons, emoji, etc. Although these signs can substitute verbal language for some people, they still lack deep meanings. Even though ethnodesign supporters insist on the relevance of translating the meanings from different cultures in the forms and images of modern design (11), this idea is utopian: "An ethnic object only becomes a text containing certain information if a person can perceive its cultural basis" (Kukhta 2015, 161).

Same as their ancestors, modern people value the sign function of costumes that allow not only designating the social status of the wearer (although in a much more subtle form than in the class-based or classical capitalist society) but also demonstrating their political views and social position (for example, environmental), yet never regional, confessional, or national affiliation. The Western society sharing liberal values sometimes even condemns such behavior as illustrated by the UK legal processes of 2012 related to the ban on workers and employees of British companies openly wearing Christian cross necklaces. Thus, it can be stated that by the present time folk costumes have disappeared from daily life in many world regions.

Nevertheless, this conclusion does not imply that clothing can never serve as a means of visualizing ethnicity in Western societies. Some examples of clothes performing this function in modern society (meaning every day or festive clothing worn in real life and not including the 
costumes of folk collectives and ensembles) can be found. The first example is provided by the movement of historical reenactors and modern pagans; however, these groups constitute a negligible percentage in any society. The second example is the elements of national costumes having a pronounced political significance as an indicator of belonging to the main ethnic group of the country and supporting the policy of nationalism like vyshyvankas in Ukraine. This phenomenon can be compared to the love for tracts in the Third Reich. The third situation is the preference for traditional costumes as wedding clothing among the small-numbered peoples as a way of maintaining their ethnic identity and a means of ethnic self-affirmation (which corresponds to the processes of glocalization). The fourth situation is another example of glocalization migrants wearing the elements of traditional costumes (for example, skullcaps and Kyrgyz "kalpaks", especially to Friday prayers) as a way of self-affirmation not only in Western Europe but also in Russia. Finally, the most short-lived and superficial option is associated with the influence of events of great international resonance. This example is illustrated by the sudden popularity of kokoshnicks as souvenirs during the 2018 FIFA World Cup in Russia - this momentary fashion was clearly kitschy and carnival at the same time.

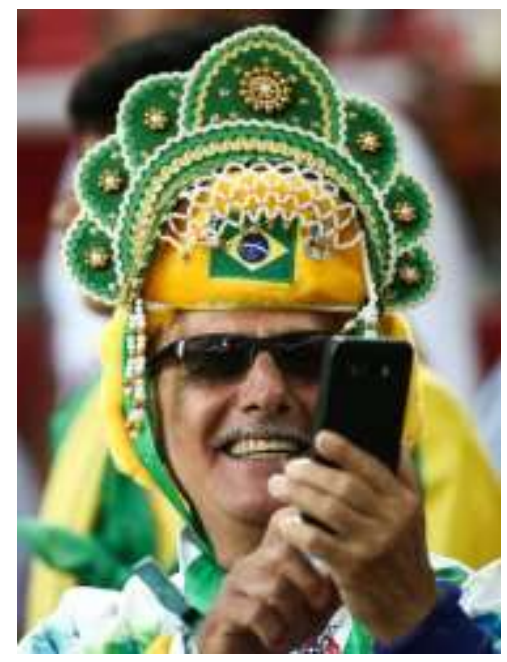

Fig. 10. Brazilian fan at the 2018 FIFA World Cup in Moscow

(URL: https://dzertv.ru/29692-matchi-na-vylet-kto-favority/)

\section{Discussion}

Although the elements of the traditional material culture of various regions are included in the modern material culture through the means of ethnic style, it cannot be interpreted as a means of visualization of ethnicity since it targets all consumers regardless of their nationality. Designers who work in ethnic style use stylization, the collage method, borrow and transform the elements of national costumes from different countries combining them with the elements borrowed from other creative sources. This leads to the "superficial", "surface" attitude towards the source - designers typically "play" with ornamental motifs, patterns, color combinations, and shapes without caring about preserving their original meaning.

It should be noted that in the 2010 s the popularity of ethnic motifs in fashionable clothing started to decline. It can be assumed that the reason for this was the influence of the European migration crisis in Europe as a result of the "Arab Spring" in North Africa and the war in Syria when ethnic motifs in clothing started to be perceived rather negatively. However, this topic calls for 
specialized research since so far the consequences of the migration crisis have been studied mainly from the political and socio-economic viewpoints (Muidinov 2019).

One of the unresolved problems in the theory of ethnodesign (which, perhaps, is unsolvable altogether) which is very rarely discussed is the problem of determining the potential consumers of ethnodesign since the percentage of people who are able to "read" the meanings contained in traditional forms is highly limited. Even in traditional costumes "all signs and symbols could be understood only by people who belonged to a specific group of people since every nation had its own costume language" (2, p. 54). Costumes have always been a "friend or foe" insignia. A "friend" or a "foe" was always easily identified by their costume. However, only "friends", i.e., the representatives of the ethnos in question could understand all semantic nuances conveyed in ornamental motifs, color combinations, and costume elements. The followers of ethnodesign typically do not specify the target audience of their projects - whether it is intended for the representatives of a specific ethnos related to a regional tradition or for a modern person in general, "a citizen of the world". The second option appears more relevant which is supported by the success of Japanese designers outside of Japan primarily among European consumers (Kawamura 2004, 42). It can be assumed that ethnodesign has become a noticeable phenomenon of modern design culture not due to such projects being demanded by a particular ethnic group (although this is possible on a local scale, and here we do not refer to regional authorities) but due to the fact that it presents a direction of world design the purpose of which lies primarily in the semantic enrichment of the material environment.

\section{Conclusion}

The conducted study demonstrates that:

- Despite the wide spread of European urban fashion and almost complete disappearance of traditional costume as daily wear in most regions of the world, partial preservation of the function of ethnicity visualization in modern costumes can be noted. Traditional costumes are worn in special occasions, mostly weddings, by the representatives of national minorities as a symbol of national identity and self-affirmation;

- Ethnic style in fashion does not present a means of demonstration of a person's ethnic identity since it is inspired by various ethnic motifs and is perceived by a consumer as an opportunity to demonstrate their individuality;

- Ethnodesign follows the principle of deep and thoughtful care about tradition and the preservation of the values of traditional cultures based on the study of the patterns of its formation. Similar to ethnic style, ethnodesign can use various methods of interpretation of the source, however, it aims to preserve the initial meaning of these motifs including the symbolism of traditional ornaments as much as possible. The remaining problem lies in the fact that modern people do not perceive the ancient language of symbols;

- Nevertheless, in some cases, modern clothing does serve the function of visualization of ethnicity. The topics of preservation of traditional costumes and their elements for migrants, as well as the influence of the European migration crisis on the attitude towards ethnic motifs in costumes, call for specialized research. 


\section{Notes}

i The Christian Science Monitor. September 26, 1973.

ii Big Russian Encyclopedia https://bigenc.ru/philosophy/text/2000174 (Accessed April 28, 2020)

\section{References}

Bogatyrev P.G. 1971. Funktsii natsional'nogo kostiuma v Moravskoi Slovakii [Functions of the national costume in Moravian Slovakia]. Bogatyrev P.G. Voprosy teorii narodnogo iskusstva. Moscow, Iskusstvo.

Boeva O.A. 2011. Znakovye funktsii i simvoly traditsionnoi narodnoi odezhdy [Sign functions and symbols of traditional folk clothing]. Ivzestia of the Volgograd State Pedagogical University. Volgograd, VSPU.

Vasilchenko A.V. 2009. Moda i fashizm. [Fashion and fascism.]. Moscow, Veche.

Golovnev A.V. 2017. Arkticheskii etnodizain [Arctic ethnodesign]. Ural Historical Journal, Ekaterinburg, the Institute of History and Archaeology of the Ural Branch of the Russian Academy of Sciences, Iss. 2.

Danilova O.N. 2019. Tsiklicheskaia paradigma v issledovanii predstavlenii o koevolyutsii etno- i ekodizaina kostiuma [Cyclic paradigm in the study of ideas about the co-evolution of ethno- and eco-design of a costume]. Territoriia novykh vozmozhnostei. Vestnik Vladivostokskogo gosudarstvennogo universiteta ekonomiki i servisa., Vol. 11, № 2.

Dobrovolskaia V.E. 2015. Narodnyi kostium i sovremennaia odezhda: znakovye funktsii v proshlom i nastoiashchem. [Folk costume and modern clothing: sign functions in the past and the present]. Funktsionalno-strukturalnyi metod P.G. Bogatyreva v sovremennykh issledovaniiakh folklora: Sbornik statei i materialov. Moscow: The State Institute for Art Studies of the Ministry of Culture of the Russian Federation.

Ermilova D.Iu. 2019. Istoriia kostiuma. Uchebnik dlia vuzov. [Costume history. Textbook for universities]. Moscow: Iurait Publishing House.

Ermilova D.Iu. 2019. Teoriia mody. Uchebnoe posobie dlia vuzov. [Fashion theory. Textbook for universities]. Moscow, Iurait.

Kalashnikova N.M. 2002. Narodnyi kostium (semioticheskie funkctsii). [Folk costume (semiotic functions)]. Moscow, "Svarog".

Kondrateva K.A. 200o. Dizain i ekologiia kultury. [Design and ecology of culture]. Moscow: Moscow State Stroganov Academy of Industrial and Applied Arts.

Kukhta M.S. 2015. Etnodizain kak osnova formirovaniia tolerantnogo otnosheniia k traditsiiam raznykh kultur [Ethnodesign as the basis for the formation of tolerance towards the traditions of different cultures]. Vestnik of the Tuva State university. Social and Human Sciences. Kyzyl,№ 1.

Levkievskaia E.E. 2011. Narodnaia odezhda. Semantika i pragmatika. [Folk clothing. Semantics and pragmatics]. Kody povsednevnosti v slavianskoi kulture: eda i odezhda. Saint Petersburg, Aleteiia.

Liausheva S.A., Pozdniakova T.S. 2019. Realizatsiia etnichnosti v protsesse reprezentatsii v sovremennom simvolicheskom prostranstve (regionalnyi aspekt) [Realization of ethnicity in the process of representation in the modern symbolic space (regional aspect)]. Quarterly peer-reviewed, refereed scientific journal, Vestnik of the Adyghe State Univarsity", Issue 1 (234).

Maslova G.S. 1978. Ornament russkoi narodnoi vyshivki kak istoriko-etnograficheskii istochnik. [Ornaments of Russian folk embroidery as a historical and ethnographic source.] Moscow: Nauka. 
Maslova G.S. 1984. Narodnaia odezhda v vostochnoslavianskikh traditsionnykh obychaiakh i obriadakh XIX nachala XX. [Folk clothes in East Slavic traditional customs and rituals of the 19th - early 2oth centuries.] Moscow, Nauka.

Muidinov D.N. 2019. Vliianie migratsionnykh protsessov na politicheskuiu i sotsialno-ekonomicheskuiu stabilnost $\mathrm{v}$ Evrope [Impact of migration processes on the political and socio-economic stability in Europe]. The Bulletin of the Volga Region Institute of Administration. Vol 19, № 2. Saratov, Povolzhsky Institute of Management named after P.A. Stolypin.

Petrov I.G. 2017. Funktsii odezhdy v svadebnoi obryadnosti chuvashei [Functions of clothes in the wedding rituals of the Chuvash people]. Istoricheskie, filosofskie, politicheskie i iuridicheskie nauki, kulturologiia $i$ iskusstvovedenie. Voprosy teorii i praktiki.Tambov: Gramota, № 11(85).

Poidina T.V. 2018. Etnicheskaia traditsiia kak stileobrazuiushchaia kategoriia v regionalnom dizaine [Ethnic tradition as a style-forming category in regional design]. Tomsk State University Journal of Cultural Studies and Art History. Tomsk, TSU, № 29.

Sodnompilova M.M. 2013. Traditsionnaia odezhda mongolskikh narodov v rituale i kak instrument socializatsii [Traditional clothes of Mongolian peoples in rituals and as an instrument of socialization]. The Bulletin of Irkutsk State University. Irkutsk, ISU, № 2 (3).

Cleveland M., Laroche M. 2007. Acculturation to the global culture: Scale development and research paradigm // The Journal of Business Research, № 60.

Eicher J. 20oo. Dress. Routledge International Encyclopedia of Women: Global Women's Issues and Knowledge. Ed. by C. Kramarae and D. Spender. N.Y.: Routledge, P. 422.

Fieschi A. 2002. Kimono, d'art et de desir. Philippe Picquier.

Fox K. 2004. Watching the English: The Hidden Rules of Behaviour. London: Hodder \& Stoughton,- VII.

Kawamura Y. 2004. The Japanese Revolution in Paris Fashion. Oxford; N.Y.: Berg

Roudomet V. 2016. Theorizing glocalization: Three interpretations //European Journal of Social Theory. Vol. 19 (3).

Ross H. C. 1989. L'art du costume de l'Arabie: profil de l'Arabie Saoudite. Arabesque.

Seeling C. Fashion: The Century of the Designer 1900-1999. Published by Konemann, Cologne, 2000.

Swyngedouw E. 2004. Globalisation or Glocalisation? Networks, Territories and Rescaling// Cambridge Review of International Affairs, № 17 (1).

Vincent P-E., Cailleau R. 2008. Saris E turbans: en Inde sur les chemins du vent.- Globe Publishing.

Wickramasinghe N. 2006. Invention du vetement national au Sri Lanka :habiller le corps colonise.- Karthala. 